\title{
EKSPLORASI BAKTERI ASAL JAMUR Ganoderma sp. SEBAGAI POTENSIAL ANTAGONIS PENYAKIT TANAMAN Coriolus versicolor
}

\section{(Bacterial Exploration from Ganoderma sp., as A Potential Antagonist of Coriolus versicolor Plant Disease)}

\author{
Widyastini Dabamona ${ }^{1}$ Nunang L. May ${ }^{1 \bowtie}$ dan Descarlo Worabai ${ }^{1}$ \\ Jurusan Kehutanan, Fakultas Kehutanan Universitas Papua Manokwari, Papua Barat, \\ 98314. Tlp/Fax: +62986211065 . \\ \Penulis Korespondensi: Email: nunangmay@gmail.com \\ Diterima: 30 Sept 2019| Disetujui: 21 Okt 2019
}

\begin{abstract}
Abstrak
Tujuan dari penelitian ini menguji respon bakteri asal jamur Ganoderma sp. terhadap penyakit tanaman Coriolus versicolor secara in vitro. Tahapan dalam penelitian ini dibagi dalam 6 bagian yaitu: 1) pengambilan jamur di lapangan, 2) pembuatan media, 3) isolasi bakteri asal jamur Ganoderma sp., 4) perbanyakkan biakan penyakit tanaman, 5) pemurnian bakteri dan 6) uji antagonis. Uji antagonis menggunakan metode rancangan rancangan acak lengkap (RAL) yang terdiri dari 5 perlakuan dan diulang sebanyak 3 kali. Hasil eksplorasi bakteri didapatkan 4 jenis bakteri antagonis. Bakteri antagonis memiliki bentuk morfologi yang berbeda-beda dilihat berdasarkan bentuk koloni, tepian koloni dan warna koloni. Keempat bakteri antagonis asal jamur Ganoderma sp. menunjukkan bahwa mampu menghambat pertumbuhan radial miselium dari jamur patogen Coriolus versicolor. Persentase penghambatan yang ditunjukkan dari keempat bakteri yang diujikan berbeda-beda. Pada pengujian antagonis terhadap pertumbuhan radial miselium jamur patogen Coriolus versicolor, penghambatan paling tinggi sampai terendah ditunjukkan oleh bakteri dengan kode isolat GC4 sebesar 90,00 \%, GC1 sebesar 89,44\%, GC3 sebesar $66,11 \%$ dan GC2 sebesar 53,11\%. Persentase penghambatan pertumbuhan miselium jamur patogen Coriolus versicolor pada GC4 memiliki pertumbuhan radial miselium paling rendah yaitu $0,90 \mathrm{~cm}$ dibandingkan dengan $\mathrm{GC} 2$ dengan persen penghambatan pertumbuhan radial miselium paling tinggi $3,75 \mathrm{~cm}$.
\end{abstract}

Kata kunci: bakteri, Ganoderma sp., antagonis, Coriolus versicolor, fitopatogen

\begin{abstract}
The purpose of this study was to determine the number, morphological and antagonistic responses of bacteria from Ganoderma sp., against Coriolus versicolor plant disease. The experiment was divided into 6 parts: mushroom preparation in field, media preparation, bacterial isolation from fungus Ganoderma sp., multiply plant culture, bacteria purification, and antagonistic test using completely randomized design (RAL) experiment that consisting of 5 treatments and repeated 3 times. There were 4 types of bacteria from Ganoderma sp., that had an ability to inhibit the growth of radial mycelium of the pathogenic fungus Coriolus versicolor. The highest percentage of inhibition of GC 4 bacteria isolate was $90.00 \%$ with the lowest radial mycelium growth of $0.90 \mathrm{~cm}, \mathrm{GC1}$ $89.44 \%$ with radial mycelium growth of $0.95 \mathrm{~cm}, G C 366.11 \%$ with growth of mycelium
\end{abstract}


$3.05 \mathrm{~cm}$ and $G C 253.15 \%$ with $3.72 \mathrm{~cm}$ radial mycelium growth. The difference in percent value of inhibition is thought to be due to the comparison of nutrients, the ability to compete and antibiosis between bacterial isolates derived from Ganoderma sp.

Keywords: bacteria, Ganoderma sp., antagonis, Coriolus versicolor, phytopathogen

\section{PENDAHULUAN}

Tumbuhan sebagai produsen makanan sangat berperan penting bagi kelangsungan hidup manusia dan makhluk hidup lainnya. Peranan tersebut disebabkan adanya kemampuan tanaman yang memiliki zat hijau daun, mampu mengubah energi matahari menjadi energi kimia dan tersimpan sebagai biomasa. Kehidupan tumbuhan di alam cenderung bersifat dinamis, dengan kata lain tumbuhan tidak resisten terhadap gangguan lingkungan. Gangguan yang terjadi berasal dari gangguan biotik maupun abiotik. Salah satu gangguan biotik yang mempengaruhi pertumbuhan dan perkembangan tanaman adalah penyakit tumbuhan (fitopatogen).

Fitopatogen dapat membatasi produksi pertumbuhan tanaman baik tanaman pangan, perkebunan, hortikultura dan hutan. Implikasi serangan penyakit bagi tanaman adalah menurunnya kuantitas tanaman, degradasi kualitas produk tanaman, pembatasan jenis tanaman dan industri di wilayah produksi, gagal panen, menurunnya pendapatan petani, memicu kelaparan, kematian dan perpindahan penduduk serta pengubah kebijakan pemerintah (Stakman and Harrar 1957 dalam Soesanto 2009). Kondisi tersebut jika terus berlangsung maka dapat menyebabkan problema sosial yang mempengaruhi eksistensi kehidupan manusia. Fenomena di atas perlu dicari solusinya melalui pendekatan, prefentif dan kuratif.
Pengendalian penyakit tanaman dapat dilakukan dengan cara kimiawi, fisikmekanik, dan biologis. Cara praktis yang sering digunakan adalah teknik kimiawi dengan menggunakan bahanbahan kimia untuk memusnahkan patogen. Penggunaan bahan kimia sangat cepat membasmi mikroba penyakit namun meninggalkan dampak lainnya. Problem lingkungan dan kesehatan manusia adalah dampak utama yang ditimbulkan akibat penggunaan bahan kimia. Selain itu secara finansial penggunaan bahan kimia relatif lebih mahal.

Pengendalian fitopatogen secara biologis merupakan alternatif yang tidak berimplikasi negatif terhadap lingkungan. Pemanfaatan mikroorganisme sebagai agen hayati yang bersifat antagonis dapat menekan, menghambat atau menghilangkan populasi patogen tanaman. Bakteri merupakan salah satu mikroorganisme yang dapat digunakan sebagai agen hayati pengendalian patogen tanaman (Sinaga 2009).

Tujuan dilakukan penelitian ini adalah menguji respon bakteri asal jamur Ganoderma sp., terhadap penyakit tanaman Coriolus versicolor secara in vitro yangmana manfaat dari penelitian ini adalah mendapatkan informasi tentang bakteri asal jamur Ganoderma sp., yang memiliki peran antagonis bagi penyakit tanaman Coriolus versicolor. 


\section{METODE PENELITIAN}

Penelitian ini dilaksanakan pada Laboratorium Silvikultur Fakultas Kehutanan Universitas Papua selama kurang lebih 3 bulan yakni bulan Maret s/d Mei tahun 2018. Variabel yang diamati dalam penelitian ini yaitu pertumbuhan radial miselium jamur asal Coriolus versicolor yang diuji dengan bakteri asal jamur Ganoderma sp.

\section{Prosedur Penelitian}

Pengambilan jamur di lapangan

Pengambilan jamur Ganoderma sp., di kawasan Hutan Pendidikan Anggori Manokwari, dibawah tegakan Albizia falcataria dengan titik koordinat log: 0.847170352935791 dan long: 134.09131050109863 .

Isolasi Bakteri

Jamur Ganoderma sp., dicuci di bawah air mengalir dengan menggunakan sunlight lalu tiriskan. Isolasi bakteri dilakukan secara aseptik pada laminar airflow cabinet, langkah awal, lakukan sterilisasi dengan menyemprotkan alkohol pada permukaan jamur. Jamur Ganoderma sp., yang sudah steril di cacah, kemudian masukkan kedalam botol yang berisi air steril sebanyak $100 \mathrm{ml}$ untuk diekstrak dan digojok selama 5 menit. Ekstrak yang dihasilkan selanjutnya dibuat seri pengenceran hingga tingkat pengenceran ke 4 dengan mengambil $10 \mathrm{ml}$ ekstrak dan dimasukkan ke dalam botol yang berisi $100 \mathrm{ml}$ air steril. Masing-masing seri pengenceran tersebut diambil sebanyak $1 \mathrm{ml}$ lalu diteteskan pada media NA dengan membuat empat titik. Selanjutnya diinkubasi pada suhu ruangan $25{ }^{\circ} \mathrm{C}$ selama 2-3 hari, untuk mendapatkan koloni bakteri (May 2011).

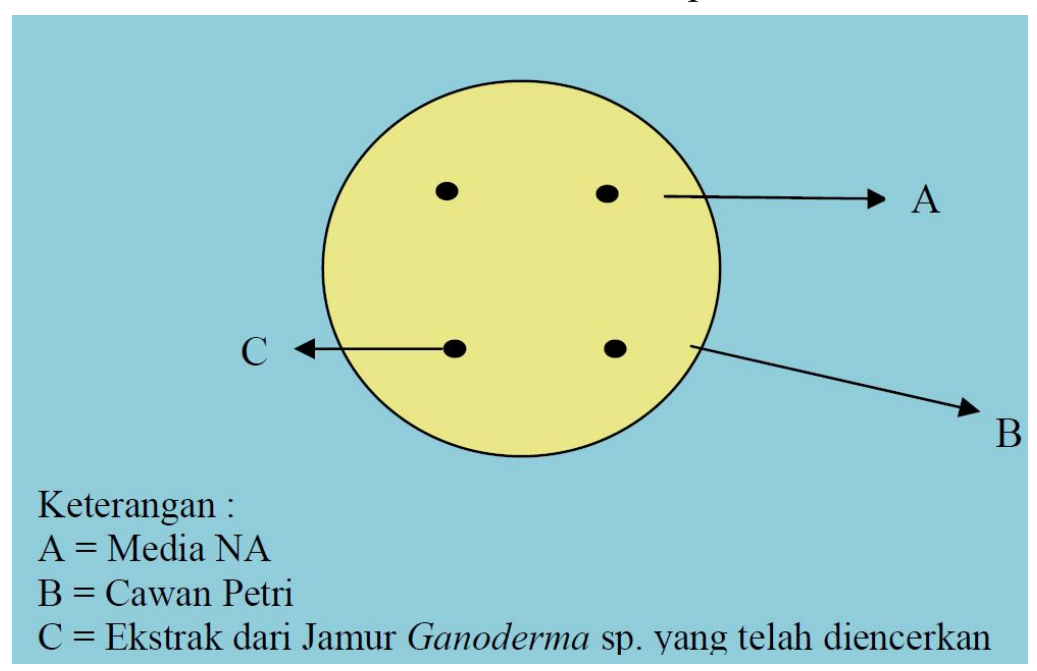

Gambar 1. Model pengenceran dari ekstrak jamur Ganoderma sp.

Perbanyakkan Biakan Penyakit Tanaman

Penyakit tanaman yang digunakan dalam penelitian ini adalah Coriolus versicolor. Perbanyakkan biakan murni dilakukan secara aseptik pada laminar airflow cabinet, dengan cara membuat lubang ukuran $0,2 \mathrm{~cm}$ menggunakan cop bor pada cawan petri yang telah terisi media PDA. Selanjutnya miselium jamur patogen diambil dengan cop bor sesuai 
ukuran lubang yang telah dibuat. pada suhu ruangan $25{ }^{\circ} \mathrm{C}$ selama 2-3 hari Miselium tersebut selanjutnya diinkubasi (Wenno 2015).

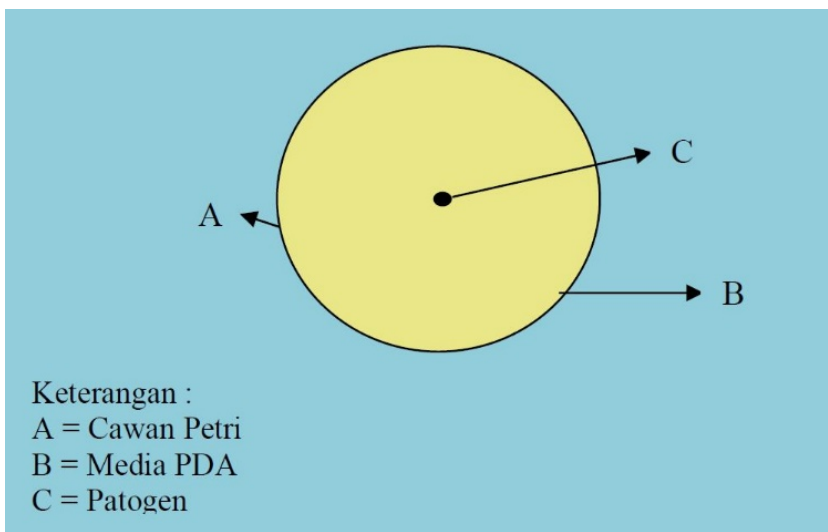

Gambar 2. Model isolasi jamur patogen asal Coriolus versicolor secara in vitro

\section{Pemurnian Bakteri}

Bakteri yang telah didapatkan dari jamur Ganoderma sp., kemudian dimurnikan. Pembuatan biakan murni dari bakteri-bakteri tersebut dilakukan secara aseptik pada laminar airflow

cabinet dengan menggoreskan bakteri menggunakan jarum ose pada media NA dalam cawan petri, selanjutnya bakteri diinkubasi pada suhu ruangan 25 ${ }^{\circ} \mathrm{C}$ selama 2-3 hari (Wenno 2015).

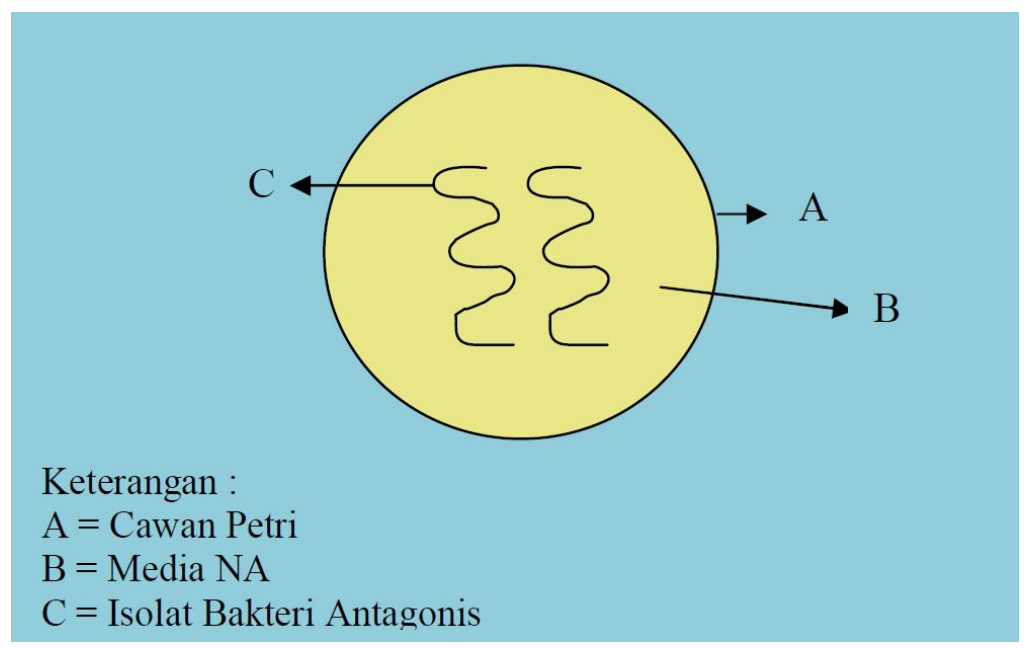

Gambar 3. Model reisolasi isolat bakteri antagonis secara in vitro

Pengujian Bakteri Pada Penyakit Tanaman (Uji Antagonis)

Uji antagonis bakteri pada penyakit tanaman dilakukan secara in vitro untuk melihat adanya sifat antagonis dari

bakteri hasil isolasi terhadap penyakit tanaman. Metode pengujian dilakukan menurut Varese et al. (1996). Bakteri ditumbuhkan pada cawan petri 
berukuran $9 \mathrm{~cm}$ yang berisi media PDA, setelah itu diambil koloni penyakit tanaman dan ditempatkan pada jarak 1 $\mathrm{cm}$ dari bagian terluar cawan petri. Cawan petri direkatkan dengan plastik wrap dan diinkubasi dalam keadaan gelap pada suhu $25{ }^{\circ} \mathrm{C}$ dengan batas waktu pengamatan hingga penuhnya penyakit tanaman pada kontrol (May 2011). Pengamatan dilakukan dengan mengukur pertumbuhan penyakit tanaman yang diberi perlakuan dengan yang tidak diberi perlakuan (kontrol). Data pengamatan digunakan untuk menghitung perkembangan radial miseluim dan persen.

penghambatan bakteri terhadap penyakit tanaman. Persen penghambatan dihitung dengan menggunakan rumus (May 2011) : Persen penghambatan $=100 \%$ - Persen (\%) total pertumbuhan fungi Persen total pertumbuhan fungi: $=\frac{\text { Diameter perkembangan fungi }}{\text { Total diameter cawan petri }} \times 100 \%$

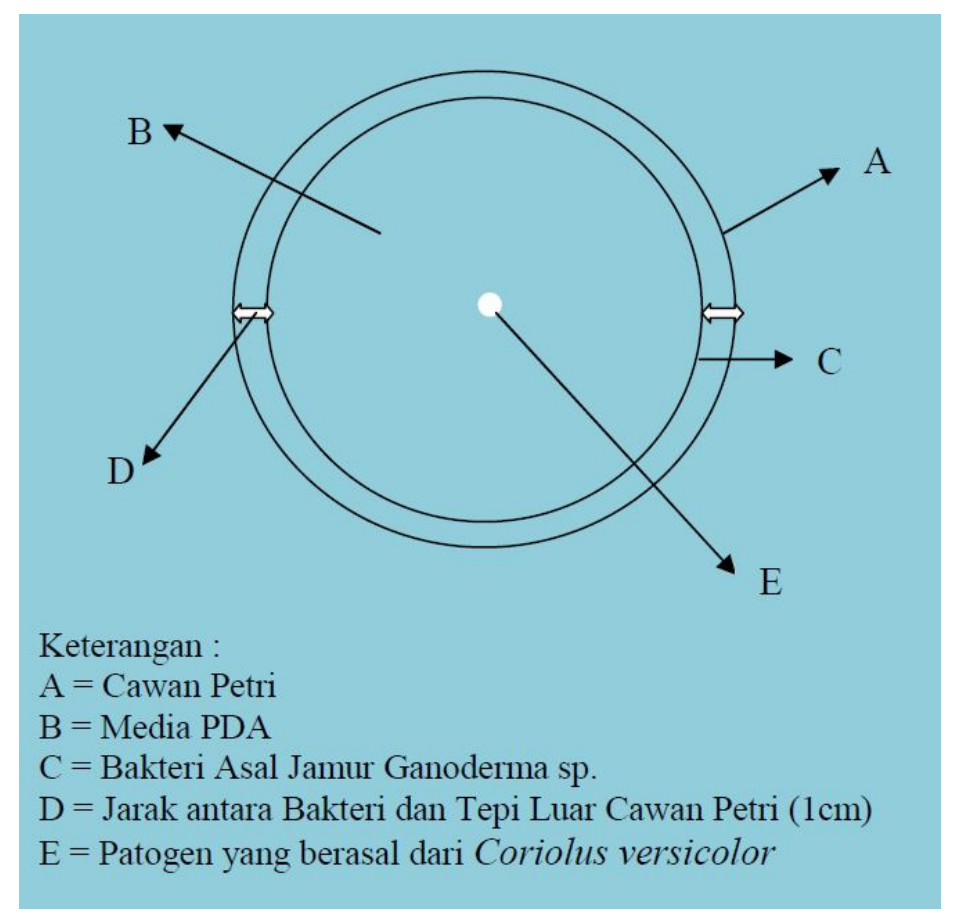

Gambar 4. Model pengujian bakteri terhadap jamur patogen berasal dari Coriolus versicolor

\section{Rancangan Penelitian dan Analisis Data}

Rancangan yang digunakan dalam uji antagonis bakteri asal jamur Ganoderma sp., terhadap jamur Coriolus versicolor adalah Rancangan Acak Lengkap (RAL) yang terdiri atas 5 (lima) perlakuan dan diulang sebanyak 3 (tiga) kali.
Perlakuan yang diberikan sebagai berikut

A : Media PDA yang ditanami jamur patogen Coriolus versicolor.

B : Media PDA yang ditanami jamur patogen asal Coriolus versicolor dan bakteri Isolat 1 .

C : Media PDA yang ditanami 
jamur patogen asal Coriolus versicolor dan bakteri Isolat 2 .

D : Media PDA yang ditanami jamur patogen asal Coriolus versicolor dan bakteri Isolat 3 .

E : Media PDA yang ditanami jamur patogen asal Coriolus versicolor dan bakteri Isolat 4 .

Model matematis rancangan acak lengkap menurut Mattjik dan Sumertajaya (2002) adalah :

$\mathrm{Yij}=\pi+\tau \mathrm{i}+\varepsilon \mathrm{ij}$

Dimana $(i=1,2,3,4, \operatorname{dan} j=1,2,3)$

Keterangan :

Yij : Hasil pengamatan dari pengamatan ke j dalam perlakuan ke-i

$\pi \quad$ : Nilai tengah pengamatan

$\tau$ i : Pengaruh peprlakuan ke-i

ij : Galat percobaan dari suatu percobaan ke $\mathrm{j}$ dalam perlakuan ke-i

Data yang diperoleh selanjutnya diolah menggunakan perangkat statistik
SPSS 16. Hasil dari olahan tersebut jika terdapat data yang signifikan maka akan dilakukan uji lanjutan Duncan. Hasil penelitian akan ditampilkan dalam bentuk tabel dan gambar.

\section{HASIL DAN PEMBAHASAN}

Hasil ekstraksi bakteri pada jamur Ganoderma sp., yang telah dilakukan secara in vitro, ditemukan empat jenis bakteri antagonis yang diujikan terhadap jamur patogen Coriolus versicolor, memiliki persentase penghambat radial miselium Coriolus versicolor yang berbeda. Persentase penghambatan tertinggi yaitu pada bakteri GC 4 sebesar $90,00 \%$ dan persentase penghambatan terendah yaitu pada bakteri GC 2 sebesar $53,15 \%$ disajikan pada tabel 1 . Sedangkan untuk perbedaan respon penghambatan perkembangan patogen dari setiap pemberian bakteri tersaji pada gambar 5 .

Tabel 1. Perkembangan radial miselium dan persen penghambatan jamur patogen Coriolus versicolor

\begin{tabular}{lcc}
\hline Perlakuan & $\begin{array}{c}\text { Perkembangan radial } \\
\text { miselium cendawan } \\
\text { pathogen }(\mathrm{cm})\end{array}$ & $\begin{array}{c}\text { Persen perhambatan } \\
(\%)\end{array}$ \\
\hline Kontrol & $9,00 \mathrm{a}^{*}$ & 0,00 \\
Bakteri GC 1 & $0,95 \mathrm{c}$ & 89,44 \\
Bakteri GC 2 & $3,72 \mathrm{~b}$ & 53,15 \\
Bakteri GC 3 & $3,05 \mathrm{~b}$ & 66,11 \\
Bakteri GC 4 & $0,90 \mathrm{c}$ & 90,00 \\
\hline
\end{tabular}

(*) Angka yang diikuti huruf yang sama menunjukkan pengaruh yang tidak berbeda nyata berdasarkan uji lanjut Duncan pada tingkat kesalahan 5\%. 


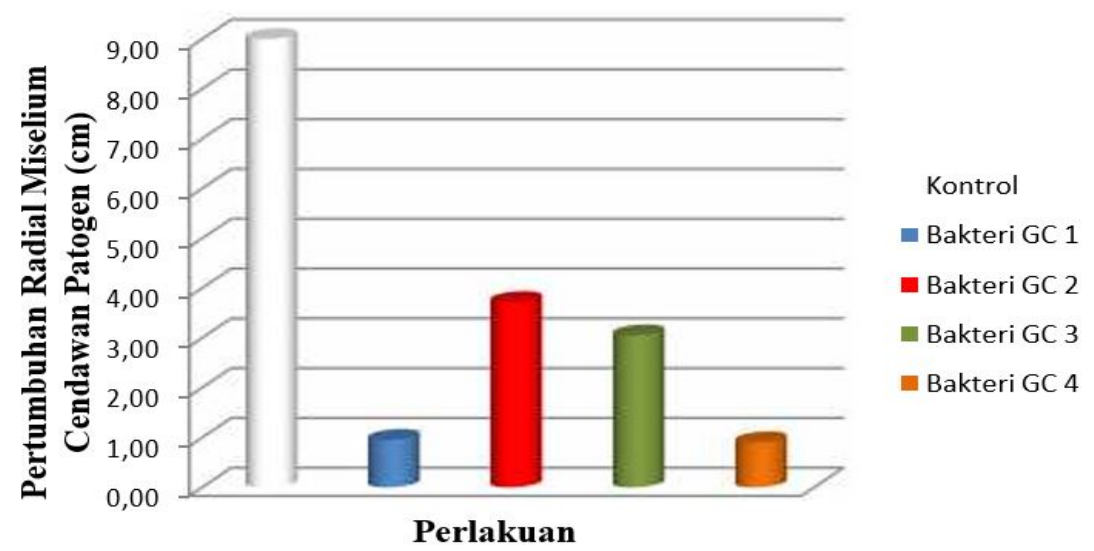

Gambar 5. Grafik penghambatan radial miselium dari cendawan patogen Coriolus versicolor

Persentase penghambatan pada tabel 1 didukung dengan uji statistik. Hasil uji statistik menunjukkan ada perbedaan persen penghambatan yang signifikan pada masing-masing perlakuan terhadap pertumbuhan radial miselium Coriolus versicolor. Dari keempat bakteri yang telah diuji, bakteri GC 4 dan bakteri GC 1 mampu menghambat pertumbuhan radial miselium jamur patogen Coriolus versicolor lebih besar dari pada bakteri GC 2 dan bakteri GC 3 yang memberikan respon penghambatan berbeda, ini terbukti dengan hasil analisis yang menunjukkan perbedaan signifikan pada pertumbuhan radial miselium jamur patogen.

Gambar 5 menunjukan bakteri GC 4 merupakan bakteri dengan persentase penghambatan pertumbuhan radial miselium jamur patogen lebih tinggi karena memiliki pertumbuhan radial miselium lebih rendah $0.90 \mathrm{~cm}$, sedangkan bakteri GC 2 merupakan bakteri dengan persentase penghambatan pertumbuhan radial miselium cendawan patogen lebih rendah karena memiliki pertumbuhan radial miselium lebih tinggi yaitu $3,75 \mathrm{~cm}$. Penampilan penghambatan bakteri terhadap cendawan patogen Coriolus versicolor yang telah diuji disajikan pada gambar 6 . Jamur patogen Coriolus versicolor memerlukan pertumbuhan miselium selama 7 hari untuk memenuhi cawan petri berukuran $9 \mathrm{~cm}$. Berdasarkan hasil penelitian, penggunaan keempat bakteri antagonis yang dihasilkan dari ekstrasi jamur Ganoderma sp., yaitu isolat bakteri GC 1, GC 2, GC 3 dan GC 4 sama-sama memiliki kemampuan untuk menghambat pertumbuhan radial miselium jamur patogen Coriolus versicolor. Respon penghambatan dari masing-masing bakteri berbeda antar jenis dan perlakuan. Uji antagonis bakteri isolat GC 1 dan GC 4 terhadap jamur patogen Coriolus versicolor mampu menghambat pertumbuhan radial miselium jamur patogen paling tinggi dengan persen penghambatannya yaitu sebesar $89 \%$ - 90\%. Sedangkan penggunaan isolat bakteri GC 2 dan isolat bakteri GC 3 memiliki peran yang sama dalam menghambat pertumbuhan radial miselium jamur patogen Coriolus 


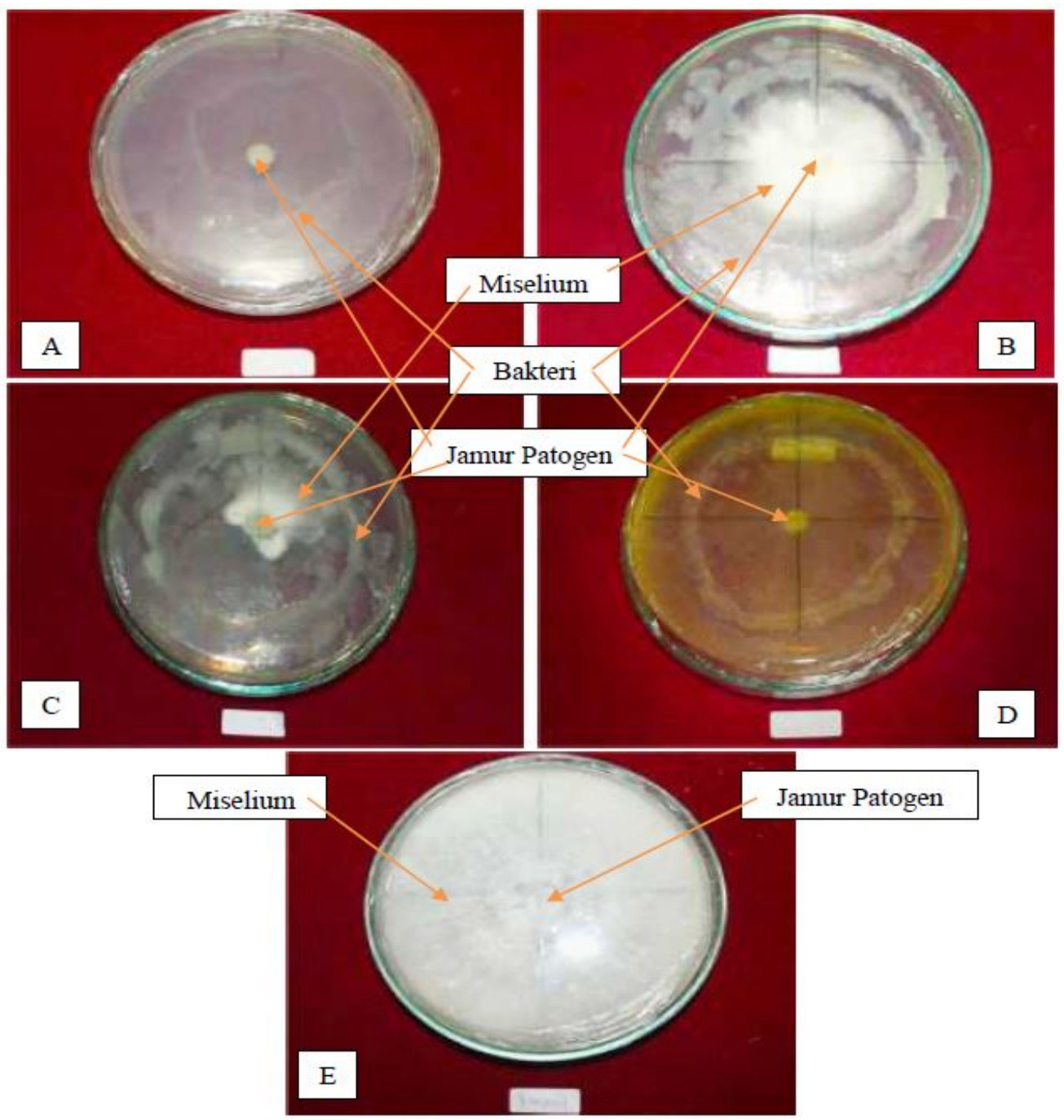

Gambar 6. Uji antagonis isolat bakteri terhadap jamur patogen Coriolus versicolor: (A) bakteri GC 1, (B) bakteri GC2, (C) bakteri GC3, (D) bakteri GC4, (E) kontrol

versicolor, namun respon penghambatan kedua isolat bakteri tersebut berbeda. Isolat bakteri GC 3 memberikan respon penghambatan sebesar $66,11 \%$, pada isolat bakteri GC 2 yang memberikan respon penghambatan lebih kecil yaitu $53,15 \%$. Keempat isolat bakteri yang didapatkan dari hasil ekstraksi jamur Ganoderma sp., menunjukkan respon penghambatan $>50 \%$. Hal ini juga dilaporkan dalam penelitian May dkk.
(2013), menemukan 2 jenis bakteri yang mampu menghambat pertumbuhan jamur patogen Sclerotium sp., diatas $79 \%$ dan kemampuan untuk menghambat jamur patogen Rhizoctonia sp. antara 51\% $53 \%$.

Terjadinya perbedaan hasil persentase penghambatan pertumbuhan radial miselium jamur patogen Coriolus versicolor diduga adanya kebutuhan nutrisi, kemampuan berkompetisi dan 
antibiosis antar isolat bakteri yang berasal dari jamur Ganoderma sp., dan jamur patogen Coriolus versicolor. Hal ini sesuai dengan pernyataan Soesanto (2008) dalam Ratnasari dkk. (2014) dimana dalam uji antagonisme disebabkan adanya kebutuhan nutrisi pada media pertumbuhannya. Nutrisi yang terkandung dalam media antara lain berupa karbohidrat protein, asam amino, mineral dan elemen-elemen mikro seperti fosfor, magnesium dan kalium untuk menghambat perkecambahan spora jamur patogen. Pendapat lain menjelaskan faktor terpenting yang menentukan aktivitas mikroorganisme antagonis yaitu memiliki kecepatan pertumbuhan yang tinggi untuk melakukan kompetisi dalam hal makanan dan penguasaan ruang sehingga dapat menekan pertumbuhan jamur patogen (Djarafuddin 2000 dalam Ratnasari dkk. 2014).

Penelitian ini dapat dikatakan adanya eksploitasi oleh bakteri asal jamur Ganoderma sp., sebagai antagonis terhadap jamur patogen Coriolus versicolor, diduga bakteri yang didapatkan dari ekstraksi jamur Ganoderma sp., memiliki sifat kompetisi dan antibiosis. Sastrosuwignyo 1998 dalam Wenno 2015 mengatakan bahwa salah satu mekanisme penghambatan antagonis bakteri terhadap mikroorganisme lainnya disebabkan adanya aktivitas antibiotik yaitu dihasilkannya macam-macam zat antibiotik.

Uji antagonis bakteri GC 1, GC 2, GC 3 dan GC 4 menunjukkan adanya pembentukkan zona bening di antara jamur patogen dengan bakteri yang digunakan. Zona bening terbentuk merupakkan hasil metabolisme yang dihasilkan oleh bakteri untukk melindungi diri dan menghambat pertumbuhan patogen jamur $(\mathrm{Wu}$ et.al. 2009 dalam Suryadi dkk. 2013). Purwantisari dan Hastuti (2009) dalam Gusnawaty dkk. (2014), juga mengatakan bahwa mekanisme daya hambat yang terjadi pada uji antagonisme melalui mekanisme antibiosis ditandai dengan adanya zona bening sebagai zona penghambatan pertumbuhan bagi jamur patogen.

Menurut May (2011) kemampuan bakteri dalam menghambat perkembangan miselium jamur patogen kemungkinan berhubungan dengan adanya aktivitas enzimatik yang dihasilkan oleh bakteri, enzim hidrolik yang dihasilkan oleh bakteri dapat mendegradasi dinding sel cendawan patogen. Pendapat lain menjelaskan kemampuan bakteri sebagai agens hayati berkaitan dengan kemampuannya bersaing untuk mendapatkan zat makanan, menghasilkan senyawa metabolit sekunder seperti antibiotik, siderofor dan enzim ekstraseluler (Habazar dan Yaherwandi 2006 dalam Diarta dkk. 2016).

\section{DAFTAR PUSTAKA}

Diarta IM, Javandira C dan Widyana IK. 2016. Antagonistik bakteri Pseudomonas spp. dan Bacillus spp. terhadap jamur Fusarium Oxysporum penyebab penyakit layu tanaman obat. Jurnal Bakti Saraswati, Vol 05 (01): 71-76.

Gusnawaty, Taufik M, Tiara L dan Asniah. 2014. Karakterisasi morfologis Trichoderma spp., indigenus Sulawesi Tenggara. J. Agroteknos, vol 4 (2): 87-93.

Mattjik AA dan Sumertajaya IM. 2002. 
Perancangan percobaan dengan aplikasi SAS dan minitab. Jilid I Edisi Ke II. IPB Press. Bogor.

May NL. 2011. Diversitas bakteri asal spora fungi mikoriza arbuskula Gigaspora sp. dan Glomus sp. serta potensinya sebagai mycrrhiza helper bacteria. [Tesis]: Bogor: Program Studi Silvikultur Tropika, IPB.

May NL, Budi SW dan Wulandari AS. 2013. Karakteristik bakteri asal spora fungi mikoriza arbuskula (FMA) Gigaspora margarita yang berpotensi menghambat patogen Rhizoctonia sp. dan Sclerotium sp. secara in vitro. Prosiding Seminar Nasional I \& Pertemuan Ilmiah Tahunan Masyarakat Silvikultur Indonesia: 285-290.

Ratnasari JK, Isnawati dan Ratnasari E. 2014. Uji antagonis cendawan agens hayati terhadap cendawan Cercospora musae penyebab penyakit sigatoka secara in vitro. (Online).

http://ejournal.unesa.ac.id/index.php/lente

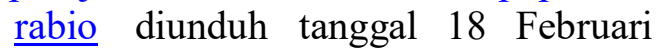
2018.

Sinaga R. 2009. Uji efektifitas pestisida nabati terhadap hama Spodoptera litura (Lepidoptera : Noctuidae) pada tanaman tembakau (Nicotiana tabacum L.). [Skripsi]: Departemen Ilmu Hama dan Penyakit Tumbuhan.
Fakultas Pertanian. Universitas Sumatera Utara. Medan.

Soesanto L. 2009. Pengendalian hayati patogen tanaman: Peluan dan tantangan dalam menunjang ketahanan pangan berkelanjutan. Pidato Pengukuhan Jabatan Guru Besar. Purwokerto (Online). https://www.researchgate.net/profile/ Loekas_Soesanto/publication/ diunduh tanggal 12 April 2018.

Suryadi Y, Priyatno TP, Samudra IM, Susilowati DN, Patricia dan Irawati W. 2013. Karakteristik dan identifikasi isolat bakteri endofik penghambat jamur patogen padi. Buletin Plasma Nutfah, Vol 19 (1): 25-32.

Varese GC, Portinaro S, Trotta A, Scannerini S, LuppiMosca AM \& Martinotti MA. 1996. Bacteria associated with Suillus grevillei Sporocarps and Ectomycorrhizae and their effects on in vitro growth of the mycobion. Symbiosis 21: 129-147.

Wenno T. 2015. Pemanfaatan bakteri asal endomikoriza sebagai antagonis cendawan patogen ikutan benih Pometia pinnata, Pterocarpus indicus dan Aquilaria filaria. [Skripsi]: Fakultas Kehutanan, Universitas Papua. (Tidak diterbitkan). 